\title{
Peculiarities of functional-vegetative homeostasis of preschool-age females (first childhood)
}

\author{
Oleh Yermishev ${ }^{\star}$ \\ Faculty of Biology, \\ Vasyl'Stus Donetsk \\ National University, \\ 600-richya St. 21, \\ 21021 Vinnytsia, Ukraine
}

In the process of ontogenesis, individual organs and systems mature gradually completing their development in different periods of life. This heterochrony of maturation determines the features of organism-functioning in children of different ages. However, the data in scientific literature do not reveal the features of the vegetative status of preschool children. Therefore, the goal of our work was to determine the level of vegetative homeostasis, which indicates the ratio of sympathetic (YANG) and parasympathetic (YIN) functional activity of the autonomic nervous system in preschool children. The methodology of functional-vegetative diagnostics (FVD) elaborated by Professor V. G. Makats (2016) allowed identifying acupunctural channels and discovered a previously unknown human functional-vegetative system. The diagnostic complex "BIOTEST-12M" (Diagnostic complexes VITA-01-M and computerized system VITA-01-Biotest) serves as the technical tool of the FVD. The specific dynamics of increasing systemic-functional stabilization indicates the formation of age-related mechanisms of functional-vegetative homeostasis and the peculiarities of physiological development of preschool children. We found $28.5 \%$ of the surveyed preschool children in the zone of vegetative equilibrium, and $50 \%$ have parasympathicotonia. The sympathetic orientation of the levels of vegetative equilibrium by the years of life of preschool children in the female group (FG) is identical and indicates the multi-directional activity of individual systemic complexes.

Keywords: age vegetology, vegetative nervous system (VNS), functional-vegetative homeostasis, functional-vegetative diagnostics (FVD)

\section{INTRODUCTION}

In the process of ontogenesis, individual organs and systems mature gradually completing their

\footnotetext{
*Corresponding author. Email: o.yermishev@donnu.edu.ua
}

development in different periods of life. This heterochrony of maturation determines the features of organism-functioning in children of different ages. The periods of growth acceleration and development alternate with their deceleration. The organs or organ systems the functioning of 
which is vital for the existence of the organism grow and develop much faster at this stage of development. Consequently, in the process of growth and development, physiological functions adapt to the peculiarities of the organism's existence, that is, it undergoes its individual adaptation to the environment (Fleming, 2011; Sikaris, 2014).

The relative immaturity of the mechanisms of regulation of somato-visceral relationships in a child's body in the process of age development, should, obviously, be considered as one of the aspects of an insufficiently perfect interaction of the autonomic nervous and any of the visceral systems (cardiovascular, digestive, respiratory, etc.), which have their own characteristics at each stage of ontogenesis (Merchant Hamid, 2016).

Sixteen to twenty years is the time during which the developing child reaches the functional level of the adult, taking into account the basic physiological parameters of the body (Jong, 2014).

Mental development of children of the preschool period (the first childhood, 4-7 years) is very rapid due to motility. The skeletal ossification process continues. The replacement of primary teeth by the permanent ones begins at the end of the period. Core and subcortical centres of the brain continue to develop; the formation of a clear language is finished. Character traits are formed at that age. Up to the seventh year of life, differentiation of the structure of the cerebral cortex is finished as well as the intense growth of the brain mass. The brain control of the cerebral cortex over intensive subcutaneous reactions develops more markedly than at the school age (Brown, 2012).

Starting from the sixth year of life, the child has the first permanent teeth: a molar (large root tooth) and a medial incisor on the lower jaw. From the first to the seventh years, secondary sexual characteristics are poorly expressed and the "type of a small child" with a large head as well as relatively short limbs predominates.

At this age the muscular system is weak and the muscles are not capable of strong and prolonged contractions. The trunk is not clearly divided into thoracic and abdominal units. The curves of the spine are not yet formed; the joints are highly mobile and the jaw system is weakly developed (Fry, 2015). This period is called "neutral childhood" since the boys and girls are not different in size and in their body shape.

The chemical composition of blood is very stable, changing relatively little with age. The amount of protein in the blood of newborns is slightly lower than that in adult blood, up to 6\% (Zierk, 2015). With age, its level increases so that the protein content in the plasma of a twomonth-old child is about 50-55 g/l; by the first year it reaches $65 \mathrm{~g} / \mathrm{l}$, by the seventh year of life $70 \mathrm{~g} / \mathrm{l}$, and at 12 years of age it is $75 \mathrm{~g} / \mathrm{l}$, i.e., like in an adult (70-80 g/l) (Adeli, 2015).

However, it is necessary to note significant individual fluctuations in the number of proteins in the blood of children of the same age group. In the blood of a child, the proportion of protein fractions is different than in an adult's blood: thus, the content of albumins in newborns is somewhat reduced, while globulins, on the contrary, are slightly increased (gamma globulins). By the third year of life the content of albumins starts to increase, reaching the adult norm by the third year of life. Thus, the protein composition of the blood during ontogenesis undergoes a number of changes. The amount of protein gradually increases. The ratio of fractions is changing, which is associated with the gradually increasing capabilities of protein-forming structures.

In children older than a year, further changes in the content of haemoglobin, erythrocytes, and leukocytes are observed, which determines a number of features of the haemogram of older children. The morphological composition of blood of children of different age groups has significant differences. The content of haemoglobin of two-year-old girls and boys is 117, at the age of four it is 126 , at the age of ten -130 , and at the age of 14 it is $160 \mathrm{~g} / \mathrm{l}$ for boys and $140 \mathrm{~g} / \mathrm{l}$ for girls, i.e., it reaches the adult norm.

The number of erythrocytes also increases, especially intensively until the fourth year of life, 
remaining at the same level during the period from four to eight years of age. Then again, there is a slight increase in the number of red blood cells per unit of blood volume. After the first year the number of leukocytes gradually decreases. In addition to that, the number of neutrophils increases and the number of lymphocytes decreases. The amount of monocytes decreases insignificantly. At the age of $4-5$, there is a second cross-section of the curve of neutrophils and lymphocytes.

The blood coagulation system, which is considered to be the most important independent physiological system, develops gradually. From the first to the 12th-14th years of age the blood content of individual factors varies individually, but on average it corresponds to the norms typical of adults. These individual fluctuations reach their maximum in the prepubertal and pubertal period, which is, apparently, associated with an unstable hormonal background in this period. The levels of most of coagulation proteins vary considerably with age (Attard, 2013; Zierk, 2015). Age is also related with a change in concentration and redistribution of some ions. Thus, when studying the concentration of chlorine in the samples of the human liver from male and female donors aged one day to 84 years $(n=97)$, it was found that the chlorine concentration decreased with age in the liver cytosol, but increased in the mitochondria of the liver (Jahn, 2015).

The data obtained from children in a series of tests confirmed that the auditory abilities undergo expressed maturation in children from the age of three and reach the maximum at different ages (up to 13), depending on the type of test used (Fior, 2009).

The interpretation of alkaline phosphatase activity in children is complex because of extensive changes connected with growth and puberty, which leads to distinctive behavioural and age-related dynamics. Continuous diagrams of changes in its activity from birth to adulthood give the possibility to accurately take this dynamics into account (Zierk, 2018).

Thus, preschool children (first childhood) are characterized by specific anthropometric, haematological, morphological, biochemical, and physiological characteristics. However, the data in scientific literature do not reveal the features of the vegetative status of preschool children.

Therefore, the goal of our work was to determine the level of vegetative homeostasis, which indicates the ratio of sympathetic (YANG) and parasympathetic (YIN) functional activity of the autonomic nervous system in preschool children.

\section{MATERIALS AND METHODS}

The methodology of functional-vegetative diagnostics (FVD) elaborated by Professor V. G. Makats (2016) allowed to identify acupunctural channels and discovers a previously unknown human functional-vegetative system. This method was approved for application in medical practice by the Academic Council of the Ministry of Health of Ukraine and by the joint session of the State Problem Commissions (RPC) of Paediatrics, Obstetrics and Gynaecology, Quantum Medicine, Haematology and Transfusiology, New Medical Technology and New Diagnostic Tools (Minutes No. 1, 08-01 of 11 September 1994). Currently, this is the only "electropunctural" diagnostics, results of which are stable and comparable in time. It is based on previously unknown biophysical phenomena. "Electropunctural" diagnostics has original standardization and is directed at the evaluation of functional-vegetative homeostasis: correlation of syndromes of sympathetic (YANG) and parasympathetic (YIN) activity.

The diagnostic complex "BIOTEST-12M", which consists of two diagnostic complexes VITA-01-M and the computerized system VITA-01-Biotest, serves as the technical component of the FVD. The latter does not use traditional external power sources and the RPC "New medical technology and new methods of diagnostics, prevention and rehabilitation" by the Ministry of Health of Ukraine (Minutes No. 5 of 25 December 25 1991) and Scientific Council of Ministry of Health of Ukraine (record No. 1. 08-01, 11 January 1994) was 
approved for practical use. The reliability of the obtained data was estimated by means of parametric and nonparametric statistics. The analysis of the results was carried out with computer programs "Search" (developed by the European Centre for Postgraduate Education of the Ukrainian National Academy of Natural Sciences). The system VITA-01-M does not require metrological standardization because: (1) the FVD methodology does not require external sources of power; (2) the voltage of the closed individually-diagnostic circuit does not exceed the level of the membrane potential $(0.03-06 \mathrm{~V})$; (3) analysis is needed not for absolute values of diagnostic indices, but for a relative correlation of the total activity of functional systems of YANG/YIN groups (syndromes of sympathetic/parasympathetic activity of functional systems).

Reasonability of functional-vegetative examination of children is confirmed by the programme "A two-stage system for rehabilitation of vegetative disorders in children residing in the zone of ecological control of Ukraine" (conducted according to the Resolution of the Cabi- net of Ministers of Ukraine No. 1861/4, 4 April 1997 and No. 12010/87, 01 June 1999).

The received data in $\mathrm{mV}$ (millivolts) or in mkA (microampere) of FVD is transformed into average values. We determined the overall bioelectric activity of functional systems of YANG and YIN groups, and the vegetative coefficient of their interdependency $\left(\mathrm{k}-\mathrm{V}=\sum\right.$ YANG: $\Sigma$ YIN). From the point of view of vegetative homeostasis, the latter points to the correlation of sympathetic (YANG) and parasympathetic (YIN) functional activity.

Functional autonomic systems ("acupuncture channels") are based on the international acupuncture nomenclature (IAN) suggested by the WHO (Table 1).

The following zones (levels) of functionalvegetative homeostasis are scientifically based on the coefficients of functional-vegetative homeostasis (Table 2).

We examined 184 females of the preschool age of 3 to 6 years (first childhood) undergoing health improvement at five Ukrainian sanatoria. FVD was held twice in the first half of the day (from 10:00 till 12:00). The bioelectric

Table 1. Acupuncture channels (meridians) according to the WHO international nomenclature

\begin{tabular}{c|cccc}
\hline Traditional channel & WHO & Traditional channel & WHO \\
\hline Lungs & LU & Bladder & BL \\
\hline Large intestine & LI & Kidneys & KI \\
\hline Stomach & ST & Pericardium & PC \\
\hline Spleen, pancreas & SP & Triple heater & TE \\
\hline Heart & HT & Gallbladder & GB \\
\hline Small intestine & SI & Liver & LR \\
\hline
\end{tabular}

Table 2. Zone (levels) of functional-vegetative homeostasis

\begin{tabular}{ccc}
\hline Value of k-V & Zones of functional-vegetative homeostasis & Symbol of zone \\
\hline to 0.75 & syndrome of significant parasympathetic prevalence & PA-s \\
\hline $0.76-0.86$ & syndrome of expressed parasympathetic prevalence & PA-e \\
\hline $0.87-0.94$ & functional compensation zone of the parasympathetic activity & FcP \\
\hline $0.95-1.05$ & zone of functional vegetative equilibrium & VE \\
\hline $1.06-1.13$ & zone of functional compensation of sympathetic activity & FcS \\
\hline $1.14-1.26$ & syndrome of expressed sympathetic prevalence & SA-e \\
\hline$>1.26$ & syndrome of significant sympathetic prevalence & SA-s \\
\hline
\end{tabular}


activity of 12 symmetric pairs of functionalactive skin zones (24 FAZs) was studied and 2016 tests were performed. Attention was drawn to the dynamics of the levels of the vegetative equilibrium (LVE) and to the direction of the dispersion of levels of integral vegetative homeostasis over the years of life in females of preschool age (3 to 6 years).

\section{RESULTS AND DISCUSSION}

Up until now, vegetative anamnesis in the form of questionnaires has been generally accepted as a means of integral evaluation of vegetative homeostasis. At the same time, historically extant isolated evaluation of sympathetic and parasympathetic reactions of basic divisions of the vegetative nervous system (VNS) contradicts contemporary ideas of their functional-dependent composition. Additionally, the complexity of study into super-segmental and segmental levels of vegetative regulation restricts necessary information for clinicians. It is also necessary to bear in mind the heterogeneity of sympathetic and parasympathetic reactions, nonlinearity of the parameters of the vegetative status during the change of activity of one of the divisions of VNS, and their dependency on a range of regulating factors. At the same time, it has been defined that the indications of instrumental examination of the VNS characterize only separate mechanisms of vegetative regulation (Makats, 2015).

The first issue of age vegetology of preschool age refers to the biophysical reality of its "functional-vegetative system" (FVS) (Makats, 2011). Functional-vegetative diagnostics developed in Ukraine (Makats, 2016) allowed identifying the "acupuncture channels" of the traditional Eastern Zhen-Tszyu therapy, proving its direct relation to the human autonomic homeostasis (Makats, 2017), and raising the question of the expediency of the problem of "age vegetology".

From the biophysical point of view, functional activity of separate acupunctural zones is not a carrier of basic information. However, the interrelation between YANG/YIN syn- dromes directly shows the prevalence of systemic excitation (sympathetic orientation of functional-vegetative activity), or oppression (parasympathetic orientation of functionalvegetative activity).

This conditions the following principles of FVD:

- overall bioelectrical activity of representative zones of the group YANG is comparable with sympathetic activity, and of the group YIN - with parasympathetic activity;

- sympathetic and parasympathetic divisions of the VNS at the organ level ensure biochemical control over the systemic vegetative equilibrium (the latter under ordinary conditions is dynamically stable; a disorder of the equilibrium is conditioned by prevalence of activity of one of the divisions of the VNS);

- the correlation of YANG and YIN syndromes at the biophysical level characterizes the functional vegetative equilibrium, i.e. interdependency of functional excitation and oppression (the latter under ordinary conditions is dynamically stable; disorder of functional equilibrium is conditioned by prevalence of one of syndromes);

- a dynamically-stable correlation of YANG and YIN syndromes probably correlates with dynamically-stable functional correlation of sympathetic and parasympathetic activity, i.e., with the functional-vegetative equilibrium;

The logical conclusion that follows is that at the organ level, sympathetic and parasympathetic divisions of the VNS act as the operator of functional-informational program of vegetative control. At the same time, the latter is conditioned by vegetative coefficients.

Before considering these materials, let us pay attention to the international terminology (Tables 1-2) which concerns the issue of our study. First of all, it concerns "acupuncture channels", or, in modern interpretation, "functional-vegetative systems" (FVS) and levels of vegetative disorders the boundary of which is determined by vegetative coefficients $(\mathrm{k}-\mathrm{V})$ (Makats, 2011).

The functional-vegetative system of the examined contingent of girls of preschool age 
is a specific biophysical reality with a special system-vegetative dynamic, which determines the expediency of the attention to the problem of "age-based vegetology of pre-school age". At the same time, we draw attention to the individual functional complexes (FC) of the "acupuncture channels": FC-1 (BL-G-ST), FC-2 (SP-LR-KI), FC-3 (SI-TE-LI), and FC-4 (LUPC-HT). According to modern knowledge, systems FC-1 and FC-3 (the growth of their activity causes the processes of excitation - sympathetic orientation) fall within the traditional YANG group, and systems FC-2 and FC-4 (the growth of their activity causes the processes of depression - parasympathetic orientation) belong to the YIN group In the female group (FG) of preschool age children the sympathetic orientation of the levels of vegetative equilibrium (LVE) is identical (Figs. 1-4).

Though, in this situation, $\mathrm{k}-\mathrm{V}$ reflects only the predicted dynamics of LVE along the line "PA-s-PA-e-FcP-VE-FcS-SA-e-SA-s" and indicates the multidirectional activity of individual systemic units: the excitation of FC-1 (BL-GBST) and FC-3 (SI-TE-LI) and suppression of FC-2 (SP-LR-KI) and FC-4 (LU-PC-HT).

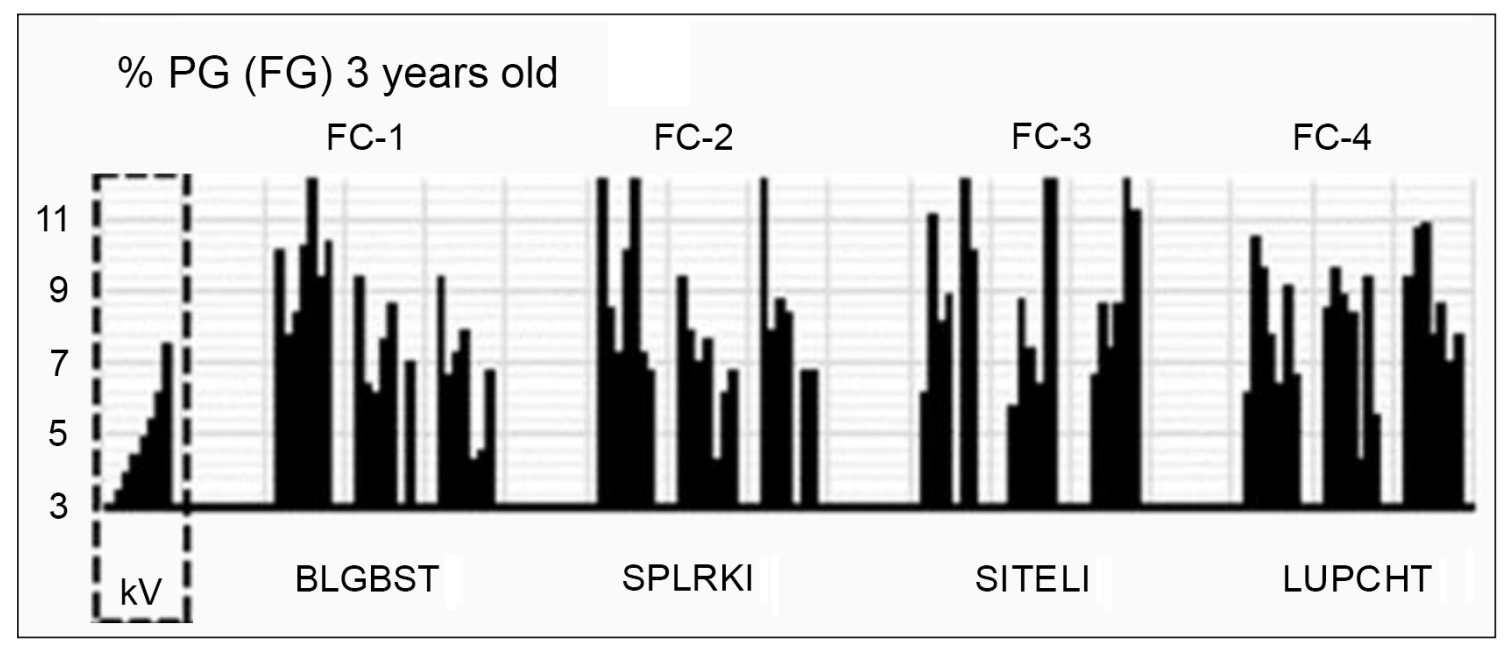

Fig. 1. The levels of vegetative equilibrium (LVE) in female group of preschool age, 3 years Here and below: PG - preschool-age group, F - female group, FC 1-4 - functional complexes, kV - vegetative coefficient

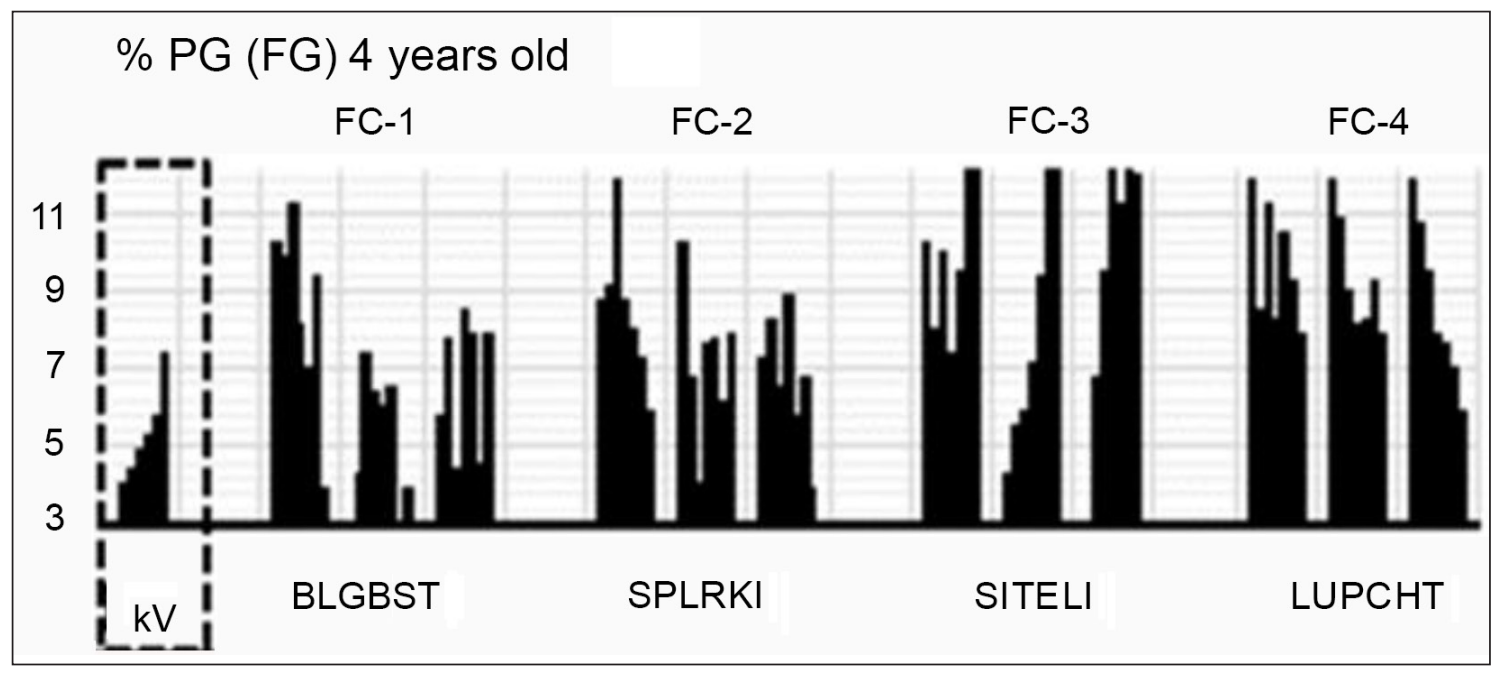

Fig. 2. The levels of vegetative equilibrium (LVE) in female group of preschool age, 4 years 


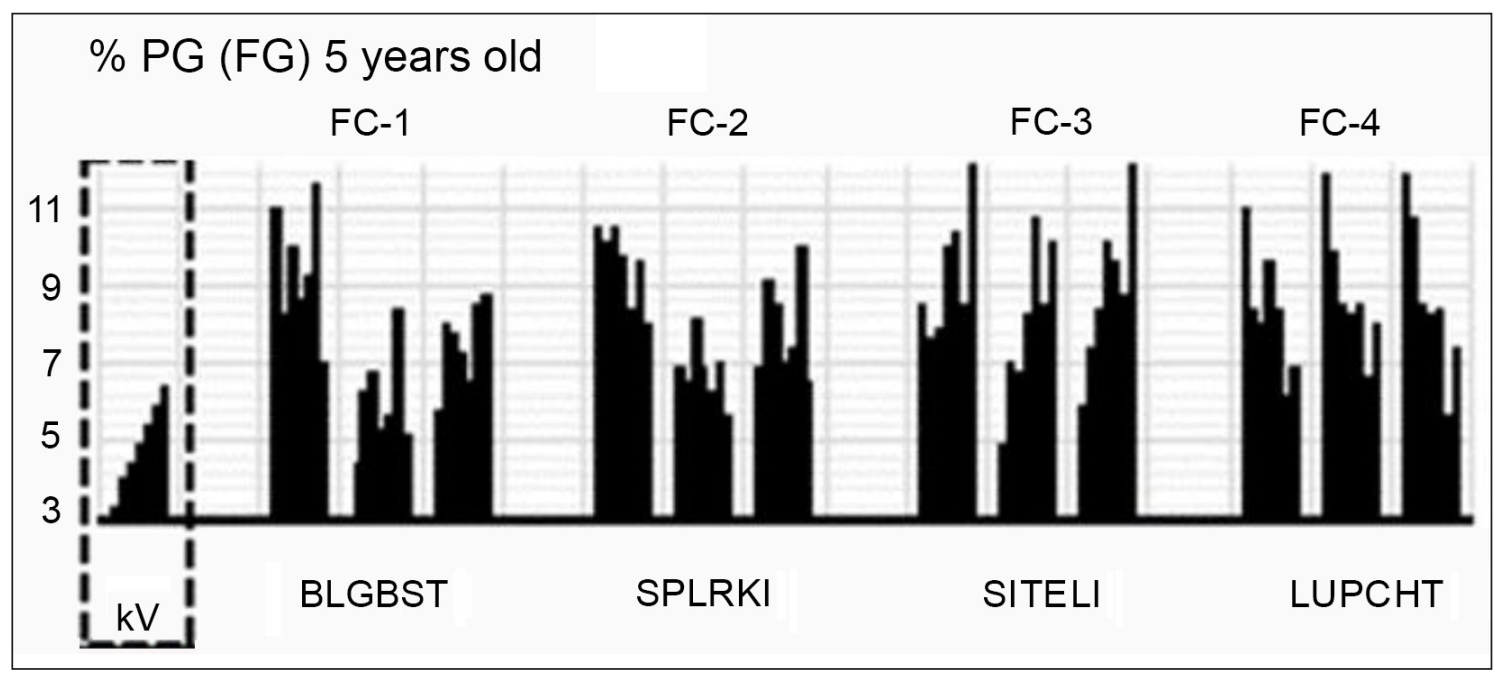

Fig. 3. The levels of vegetative equilibrium (LVE) in female group of preschool age, 5 years

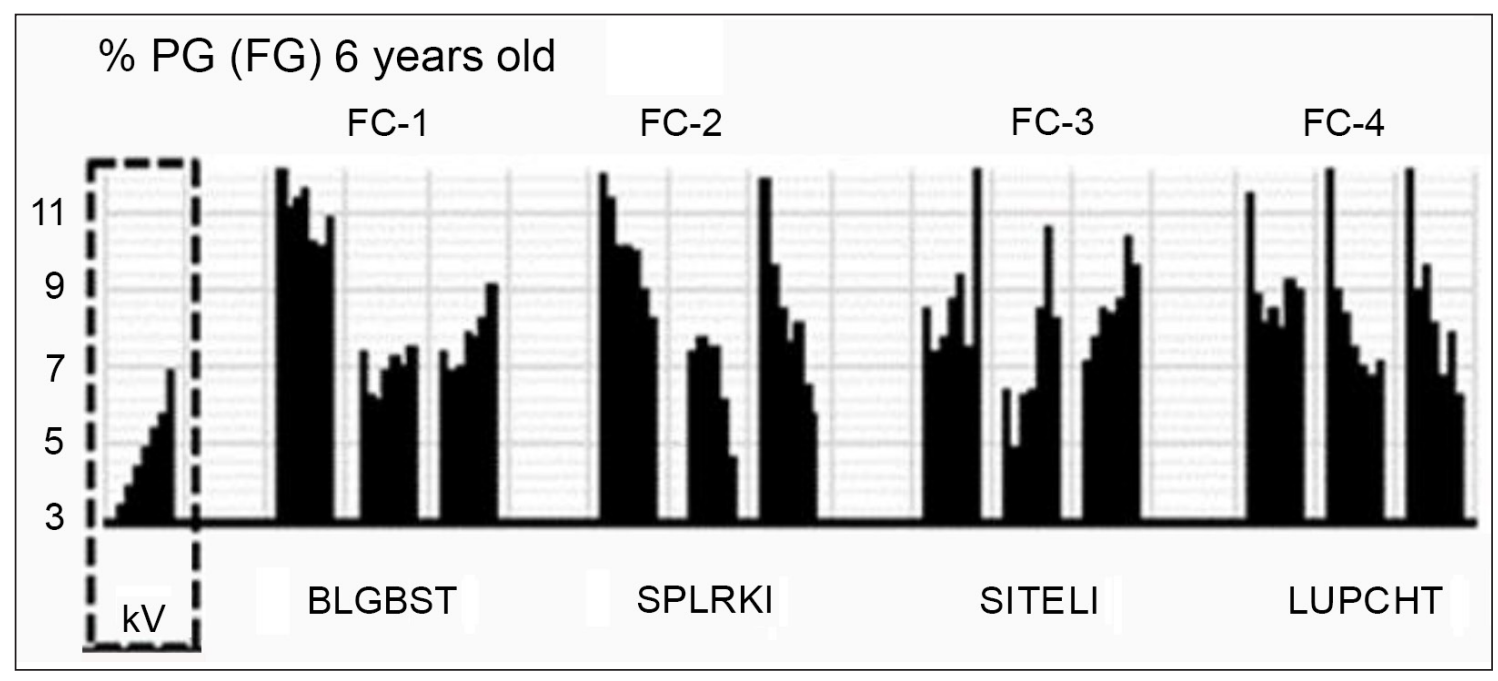

Fig. 4. The levels of vegetative equilibrium (LVE) in female group of preschool age, 6 years

In spite of its expressed chaos, the systemic activity (Table 3 ) indicates the biophysical reality of the basic mechanisms of functionalvegetative pathogenesis. Attention is drawn to the growing stabilization of some systemic reactions, which appears with years of life: during 3 to 6 years of life on the part of TE-LI FC-3 (+); during 4 to 6 years of life on the part of SP FC-2 and RC-HT FC-4 (-); during 5-6 years of life on the part of SI FC-3 (+), and during the 6th year of life on the part of BL (-) and GB-ST (+) FC-1.

In this case, the specific dynamics of increasing systemic-functional stabilization indicates the formation of age-related mechanisms of functional-vegetative homeostasis and the peculiarities of physiological development of preschool children. The revealed features point to the expediency of the section "age-based vegetology (vegetative science) of the preschool age" in the structure of the classical issue "age physiology of childhood".

At the same time, the overwhelming "paradoxically-chaotic" activity of interrelated systemic reactions is alarming, which may indicate "immaturity" of the adaptation systems of preschool children. 
Table 3. The dynamics of functional and systemic dependence on the levels of vegetative equilibrium (LVE) in a female group (FG) (\%) (directional analysis according to LVE: PAs-PAe-FcP-VE-FcS-SAe-SAs)

\begin{tabular}{|c|c|c|c|c|c|c|c|c|c|c|c|c|}
\hline \multirow{2}{*}{$\begin{array}{l}\text { Age, } \\
\text { years }\end{array}$} & \multicolumn{3}{|c|}{ FVC-1 } & \multicolumn{3}{|c|}{ FVC-2 } & \multicolumn{3}{|c|}{ FVC-3 } & \multicolumn{3}{|c|}{ FVC-4 } \\
\hline & $\mathrm{BL}$ & GB & ST & SP & LR & KI & SI & $\mathrm{TE}$ & LI & LU & PC & HT \\
\hline 3 & $\mathrm{C}$ & $\mathrm{C}$ & $\mathrm{C}$ & - & - & - & $\mathrm{C}$ & + & + & $\mathrm{C}$ & $\mathrm{C}$ & - \\
\hline 4 & - & $\mathrm{P}$ & $\mathrm{P}$ & - & $\mathrm{C}$ & $\mathrm{P}$ & $\mathrm{C}$ & + & + & - & - & - \\
\hline 5 & $\mathrm{P}$ & $\mathrm{C}$ & $\mathrm{P}$ & - & $\mathrm{P}$ & $\mathrm{P}$ & + & + & + & $\mathrm{C}$ & - & - \\
\hline 6 & - & + & + & - & - & - & + & + & + & $\mathrm{C}$ & - & - \\
\hline
\end{tabular}

Types of reactions: + synchronous; - asynchronous; $\mathrm{P}$ - paradoxical; $\mathrm{C}$ - chaotic.

Nowadays, seven levels of vegetative equilibrium (LVE) (functional and vegetative activity zones) are identified:

- PA-s (zone of significant parasympathetic prevalence; $\mathrm{k}-\mathrm{V}<0.75)$;

- PA-e (zone of expressed parasympathetic prevalence; $\mathrm{k}-\mathrm{V}$ 0.76-0.86);

- FcP (functional compensation zone of the parasympathetic activity; $\mathrm{k}-\mathrm{V}$ 0.87-0.94);

- VE (zone of functional vegetative equilibrium, when the ratio of $\mathrm{PA}: \mathrm{SA}$ within $\mathrm{k}-\mathrm{V}$ is 0.95-1.05);

- FcS (zone of functional compensation of sympathetic activity; $\mathrm{k}-\mathrm{V}$ 1.06-1.13);

- SA-e (zone of expressed sympathetic prevalence; $\mathrm{k}-\mathrm{V}$ 1.14-1.26);

- SA-s (zone of significant sympathetic prevalence; $\mathrm{k}-\mathrm{V}>1.26$.

The dispersion of vegetative equilibrium levels (LVE) causes the documentary visualization of the state of functional (vegetative) health of the child population.

The analysis of the dispersion of the levels of vegetative equilibrium (D-LVE) for particular years of life of children in the female preschool age group indicates that it points out at the bio- physical reality of functional-vegetative heterogeneity (Table 4).

The analysis of the results showed that among the surveyed three-year-old children, the highest number, $51.6 \%$, was in the vegetative balance zone (in the zone of the vegetative equilibrium) as well as in the zone of expressed parasympathetic prevalence $-22.6 \%$. Concerning four-year-old children, the highest number was in the areas of functional compensation zone of parasympathetic activity and in the zone of functional compensation of sympathetic activity $-26.1 \%$ each. As for the zone of functional vegetative equilibrium, among these children the number came up to only $17.4 \%$. The zone of functional vegetative equilibrium came to $31.9 \%$ of five-year-old children and to $19.1 \%$ in PA-e zone of expressed parasympathetic prevalence and $\mathrm{FcP}$ (functional compensation zone of parasympathetic activity).

Among six-year-old children, the highest number of the examined children was in PA-e (zone of expressed parasympathetic prevalence) - 31.9\%, in PA-s (zone of significant parasympathetic prevalence) $-20.9 \%$, although in VE (zone of functional vegetative equilibrium) the number came up to only $18.7 \%$.

Table 4. The dispersion of levels of vegetative equilibrium for years of life (YL) of girls (\%)

\begin{tabular}{c|c|c|c|c|c|c|c}
\hline \multirow{2}{*}{$\begin{array}{c}\text { Age } \\
\text { years }\end{array}$} & \multicolumn{7}{c}{ Levels of vegetative equilibrium (in \%) } \\
\cline { 2 - 9 } & PA-s & PA-e & FcP & VE & FcS & SA-e & SA-s \\
\hline 3 & 3.2 & 22.6 & 12.9 & 51.6 & 3.2 & 3.2 & 3.2 \\
\hline 4 & 4.3 & 13.0 & 26.1 & 17.4 & 26.1 & 8.7 & 4.3 \\
\hline 5 & 4.3 & 19.1 & 19.1 & 31.9 & 2.1 & 14.9 & 8.5 \\
\hline 6 & 20.9 & 31.9 & 9.9 & 18.7 & 9.9 & 8.8 & 0 \\
\hline $3-6$ & 9.2 & 25.0 & 15.8 & 28.3 & 9.2 & 9.2 & 3.3 \\
\hline
\end{tabular}


The average indicators for the age group of preschool age (3-6 years old) in the female population point to the following:

$-9.2 \%$ of the examined children in the PA-s zone;

$-25.0 \%$ in the PA-e zone;

$-15.8 \%$ in the FcP area;

$-28.3 \%$ in the VE zone;

$-9.2 \%$ in the SA-e zone;

$-3.3 \%$ in the SA-s zone.

Moreover, the small amount (only 28.5\%) of the examined children of preschool age has vegetative equilibrium (VE). It is known that prolonged vegetative disorders (the prevalence of parasympathetic or sympathetic activity of VNS) form pathogenetic mechanisms of future functional disorders.

\section{CONCLUSIONS}

1. The given data testify to the biophysical reality of "functionally vegetative system of humans", to the revealed specificity of age-related systemic dependence, and to the expediency of attention to the problem of "age (functional) vegetology (vegetative science) of the preschool age".

2. Specific dynamics of increasing systemicfunctional stabilization points to the formation of age-related mechanisms of functional-vegetative homeostasis and peculiarities of physiological development of preschool children.

3. The overwhelming "paradoxical-chaotic" activity of the interrelated systemic reactions revealed by us can point to the "immaturity" of adaptation systems of preschool-age children.

4. The analysis of the dispersion of vegetative equilibrium levels (D-LVE) for the particular years of life of children of the female preschool age group (3-6 years old) indicated the following: $25.0 \%$ were in the zone of PA-e; $15.8 \%$ in the area of $\mathrm{FcP} ; 28.3 \%$ in the VE zone; $9.2 \%$ in the SA-e zone, and $3.3 \%$ in the SA-s zone.

5 . We discovered that only $28.5 \%$ of the examined children of preschool age were found in the zone of vegetative equilibrium.

Received 30 June 2018 Accepted 8 April 2019

\section{References}

1. Adeli K, Raizman JE, Chen Y, Higgins V, Nieuwesteeg M, Abdelhaleem M, Wong SL, Blais D. Complex biological profile of hematologic markers across pediatric, adult, and geriatric ages: establishment of robust pediatric and adult reference intervals on the basis of the Canadian Health Measures Survey. Clin Chem. 2015; 61(8): 1075-86.

2. Attard C, van der Straaten T, Karlaftis V, Monagle P, Ignjatovic V. Developmental hemostasis: age-specific differences in the levels of hemostatic proteins. J Thromb Haemost. 2013; 11(10): 1850-4.

3. Brown TT, Jernigan TL. Brain development during the preschool years. Neuropsychol Rev. 2012; 22(4): 313-33.

4. Fior R. Physiological Maturation of Auditory Function between 3 and 13 years of Age. Audiology. 2009; 11: 5-6: 317-21.

5. Fleming $\mathrm{S}$, Thompson $\mathrm{M}$, Stevens $\mathrm{R}$, Heneghan C, Plüddemann A, Maconochie I, et al. Normal ranges of heart rate and respiratory rate in children from birth to 18 years: a systematic review of observational studies. Lancet. 2011; 377(9770): 1011-8.

6. Fry AC, Irwin CC, Nicoll JX, Ferebee DE. Muscular strength and power in 3- to 7-yearold children. Pediatr Exerc Sci. 2015; 27: 345-54.

7. Jahn SC, Rowland-Faux L, Stacpoole PW, James MO. Chloride concentrations in human hepatic cytosol and mitochondria are a function of age. Biochem Biophys Res Commun. 2015; 459(3): 463-8.

8. Jong G. Pediatric development: physiology. enzymes, drug metabolism, pharmacokinetics and pharmacodynamics. In: Bar-Shalom D, Rose K, editors. Pediatric Formulations. AAPS Advances in the Pharmaceutical Sciences Series, vol. 11. Springer, New York, NY. 2014; 9-23.

9. Makats Den V. Second principle issue of functional rehabilitation "Chinese Acupunctural 
Channels" as biophysical reality. J Educ Health Sport. 2015; 5(11): 261-78.

10. Makats VG, Makats EF. Unknown Chinese acupuncture (reality, errors, and problems). Vol. I. Vinnytsia: Nilan-LTD, 2016. 276 p.

11. Makats VG, Makats DenV, Makats DmV, Makats EF. Energoinformatsionnaya sistema cheloveka kak biofizicheskaya realnost. Refleksoterapevt. 2011; 4-5: 21-37. Russian.

12. Makats VG, Nahaychuk VI, Makats EF, Yermishev OV. Unknown Chinese acupuncture (problems of vegetative pathogenesis). Vol. IV. Vinnytsia: Nilan-LTD, 2017. 286 p.

13. Merchant HA, Liu F, Gul Mine O, Basit AW. Age-mediated changes in the gastrointestinal tract. Int J of Pharm. 2016; 512(2): 382-95.

14. Nijman RG, Thompson M, van Veen M, Perera R, Moll HA, Ostenbrink R. Derivation and validation of age and temperature specific reference values and centile charts to predict lower respiratory tract infection in children with fever: prospective observational study. The BMJ. 2012; 345: e4224.

15. Sikaris KA. Physiology and its Importance for Reference Intervals. Clin Biochem Rev. 2014; 35(1): 3-14.

16. Zierk J, Arzideh F, Haeckel R, Cario H, Frühwald MC, Groß H-J, Gscheidmeier T, Hoffmann R, Krebs A, Lichtinghagen R, Neumann M, Ruf H-G, Steigerwald U, Streichert T, Rascher W, Metzler M, Rauh M. Pediatric reference intervals for alkaline phosphatase. Clin Chem Lab Med (CCLM). 2018; 55(1): 102-10.

17. Zierk J, Arzideh F, Rechenauer T, Haeckel R. Age- and sex-specific dynamics in 22 hematologic and biochemical analytes from birth to adolescence. Clin Chem. 2015; 61(7): 964-73.

\section{Oleh Yermishev}

\section{IKIMOKYKLINIO AMŽIAUS (PIRMOSIOS VAIKYSTÉS) MERGAIČIŲ FUNKCINĖS VE- GETATYVINĖS HOMEOSTAZĖS YPATUMAI}

\section{Santrauka}

Ontogenezės metu atskiri žmogaus organai ir sistemos bręsta palaipsniui ir baigia vystymąsi įvairiais gyvenimo tarpsniais. Ši brendimo heterochronija lemia skirtingo amžiaus vaikų organizmo funkcionavimo ypatybes. Mokslinèje literatūroje trūksta duomenų apie ikimokyklinio amžiaus vaikų vegetatyvinę būklę, todèl mūsų darbo tikslas - nustatyti vegetatyvinès homeostazės lygi, kuris atskleidžia ikimokyklinio amžiaus vaikų autonominès nervų sistemos simpatinio (YANG) ir parasimpatinio (YIN) funkcinio aktyvumo santyki. Profesoriaus V. G. Makatso (2016) parengta funkcinès vegetatyvinès diagnostikos (FVD) metodika leido identifikuoti akupunktūrinius kanalus ir atrasti anksčiau nežinomą žmogaus funkcinę vegetatyvinę sistemą. Diagnostinis kompleksas „BIOTEST-12M“ (du diagnostikos kompleksai VITA-01-M ir kompiuterinè sistema VITA-01-Biotest) naudojamas kaip techninis FVD įrankis. Specifinè didejjančios sisteminès funkcinès stabilizacijos dinamika rodo su amžiumi susijusių funkcinès vegetatyvinès homeostazès mechanizmų formavimąsi ir ikimokyklinio amžiaus vaikų fiziologinio vystymosi ypatumus. Mūsų duomenimis, 28,5 \% apklaustų ikimokyklinio amžiaus vaikų būdinga vegetatyvinè pusiausvyra, o $50 \%$ - parasimpatikotonija. Ikimokyklinio amžiaus mergaičių grupès (FG) simpatinè orientacija ị vegetatyvinès pusiausvyros lygi yra identiška ir nurodo atskirų sisteminių kompleksų daugiakryptị aktyvumą.

Raktažodžiai: amžiaus vegetologija, vegetatyvinè nervų sistema (VNS), funkcinè vegetatyvinè homeostazé, funkcinè vegetatyvinè diagnostika (FVD) 